The Projected Destination Brand Personalities of European Capital Cities and their Positioning

Hanna, Sonya; Rowley, Jennifer

Journal of Marketing Management

DOI:

10.1080/0267257X.2019.1647274

Published: 01/08/2019

Peer reviewed version

Cyswllt i'r cyhoeddiad / Link to publication

Dyfyniad o'r fersiwn a gyhoeddwyd / Citation for published version (APA):

Hanna, S., \& Rowley, J. (2019). The Projected Destination Brand Personalities of European Capital Cities and their Positioning. Journal of Marketing Management, 35(11-12), 1135-1158. https://doi.org/10.1080/0267257X.2019.1647274

\footnotetext{
Hawliau Cyffredinol / General rights

Copyright and moral rights for the publications made accessible in the public portal are retained by the authors and/or other copyright owners and it is a condition of accessing publications that users recognise and abide by the legal requirements associated with these rights.

- Users may download and print one copy of any publication from the public portal for the purpose of private study or research.

- You may not further distribute the material or use it for any profit-making activity or commercial gain

- You may freely distribute the URL identifying the publication in the public portal ?
}

Take down policy

If you believe that this document breaches copyright please contact us providing details, and we will remove access to the work immediately and investigate your claim. 
The Projected Destination Brand Personalities of European Capital Cities and their Positioning

Dr Sonya Hanna, Bangor Business School, Bangor University, Bangor, Gwynedd, LL57 2DG Wales, UK. E-mail addresses: $\underline{\text { s.hanna@bangor.ac.uk }}$

Sonya Hanna is lecturer in Marketing at Bangor Business School. Her research interests are focused on the marketing and branding of places, in particular, the process of strategic place brand management.

Professor Jennifer Rowley, Manchester Metropolitan University Department of Information and Communications, Manchester Metropolitan University, Rosamund Street West, Manchester M15, 6LL, UK.E-mail addresses: j.rowley@mmu.ac.uk

Jennifer Rowley is Professor of Information and Communications at Manchester Metropolitan University. Her research interests embrace knowledge management, innovation, entrepreneurial marketing, branding and information behaviour. 


\title{
The Projected Destination Brand Personalities of European Capital Cities and their Positioning
}

\begin{abstract}
Capital cities are significant drivers of visitation to their countries and therefore it is important to understand how the destination brand personalities (DBP) of capital cities are projected and positioned. Hence, the aim of this research is to develop a projected DBP scale for European capital cities, and to investigate their relative positioning. Content analysis of the cities' main tourism websites was used to develop a projected brand personality scale. This was followed by correspondence analysis to investigate the relative positioning of the city brand personalities. The DBP scale included six dimensions: excitement, malignancy, peacefulness, competence, ruggedness and conservatism. Excitement is the most strongly communicated dimension across all cities, followed by peacefulness and competence. No city rated highly on ruggedness. The correspondence analysis clusters cities into three projected DBP groups: (1) Warsaw and Moscow, (2) Athens, Rome, Madrid, and Berlin, (3) Amsterdam, Paris and Vienna.
\end{abstract}

Keywords: destination brand personality; projected destination personality; cities; city positioning

Summary statement of contribution: This is the first study to explore the positioning of cities on the basis of their DBP. In addition, it contributes to the very limited body of research on projected (as opposed to perceived) destination brand personality. 


\section{Introduction}

At the heart of place branding is the notion of place identity (Kavaratzis \& Hatch, 2013). Place brand identity can be articulated in terms of benefits, values and personality traits. In the last few years, the articulation of a place brand identity in terms of its personality has been viewed as increasingly valuable for understanding the perceptions of places and for crafting a unique destination identity to enhance its brand equity (Ekinci \& Hosany 2006). Dickinger and Lalicic (2016) suggest that this is associated with a shift in focus from functional attributes to emotional attributes in branding campaigns. Various authors have observed that the functional attributes of tourist destinations alone are insufficient to attract travellers, mainly because of the growing substitutability of destinations (Bekk, Sporrle \& Kruse, 2016; Pike \& Ryan, 2004; Usakli \& Bagoglu, 2011). On the other hand, emotional attributes, since they are concerned with relationship building between visitors and destinations, have the potential to be used to increase visitor numbers (Hultman, Skarmeas, Oghazi \& Beheshti 2015). Self-congruity theory suggests that one aspect of this relationship building process is the development of an alignment between a consumer's self-concept and their perception of a destination (Sirgy \& Su, 2000). According to self-congruity theory, tourists tend to choose destinations whose typical visitor image is congruent with their own self-image (Pan, Zhand, Gursoy \& Lu, 2017). This is because tourist destinations provide an important venue in which they can create, enhance, maintain and express their self-identity (Ahuvia, 2005; Belk, 1988). Supporting this are a number of studies that have shown that an alignment between an individual's personality and place brand personality has a significant effect on intentions to purchase products, travel to and develop ties with a place (Murphy, Benckendorff \& Moscardo, 2007a; Murphy \& Papadopoulos., 2013; Rojas-Mendez, RojasMendez, Papadopoulos \& Alwan, 2015; Usakli \& Balogulu, 2011). 
Despite the growing interest in destination brand personalities (DBP's), there are some very significant research gaps. First, very few studies on DBP have focussed on cities, with most focussing on countries or nations. Yet, cities, and capital cities, in particular, are major drivers and beneficiaries of visitation to most countries. Gospodim (2004) argues that European cities are overtaking countries as driving forces of the new Europe. Mikulic, Milicevic and Kresic (2016) also suggest that "the importance of city tourism is gaining momentum and cities around the world are increasingly competing" (p. 14). In addition, since Europe is the most visited region in the world (Molina et al., 2017), understanding the branding practices and positioning of European cities is particularly pressing. Two recent studies have focused on the branding and relative positioning of European capital cities, but both focus on brand equity, not on brand personality. Hence, it is important to explore how European capital cities project and position their personalities through their branding campaigns.

Secondly, few studies have explored projected, as opposed to perceived, destination brand personality. Perceived brand personality relates to the notion of the brand personality in the eyes of the audience for the communication regarding a place; studies that examine perceived brand personality typically undertake surveys of visitors, students or residents, or a combination of these groups. Recent examples include Baloglu, Henthorne and Sahin (2014) (first-time and repeat visitors), Ishii and Wantanabe (2015) (residents), and Guerreiro, Agapito and Pech (2015) (students). Much less attention has been directed towards the study of projected DBP, the personality communicated through the various communication channels used by the destination's tourism organisation. Yet, projected personality contributes to the formulation of perceived brand personality, and furthermore, it is important that those destination marketers who are seeking to project a specific DBP have tools at their 
disposal to assess the success of their branding investment (Pitt, Opoku, Hultman, Abratt \& Spyropoulou, 2007). Only two studies have examined projected DBP; Kim and Lehto (2013) studied South Korea, whilst Pitt et al. (2007) examined ten African countries. Hence, there is considerable scope for additional studies in this area.

Finally, thirdly, since many studies on DBP have focussed on only one destination (e.g. Dickinger \& Lalicic, 2016 (Vienna); Kim \& Lee, 2015 (South Korea); Sahin \& Baloglu, 2014 (Istanbul)), the issue of brand positioning has been significantly under-researched. Yet, in a marketplace in which destination substitutability (Pike \& Ryan, 2004; Usakli \& Bagoglu, 2011; Zenker, 2009) is becoming a significant challenge, the development of methods for understanding the relative positioning of destinations is pivotal, and may have significant benefits for destination managers (Kendall \& Goursoy, 2007). Only two studies explicitly explore DBP positioning; both focussed on the perceived DBP of nations. D'Astous and Boujbel (2007) used a survey to develop a personality scale to position eleven countries, (perceived DBP), whilst Pitt et al. (2007) examined the positioning of ten African countries through a content and correspondence analysis of their websites (projected DBP).

Hence, the aim of this research is to contribute to addressing the last two gaps in the theory of DBP identified above by: (1) developing a projected DBP scale based on European capital cities; and, (2) investigating the relative positioning of the projected destination personalities of European capital cities.

The following section offer a distillation of the literature and prior theory, followed by an outline of the two-stage methodology adopted in this research. The findings are reported next, before conclusions and recommendations are offered. 


\section{Literature Review}

\subsection{Destination brand personality}

The objective of place branding is to strengthen the destination's position in an increasingly competitive marketplace (Anholt, 2005). Destination Marketing Organisations (DMOs), and other bodies associated with a place or destination invest in branding initiatives in order to attract more visitors and investors and to engage residents with their place (Blain, Levy \& Ritchie, 2005). Early destination branding initiatives focussed on destination image (Kavaratis, 2004; Peel \& Lloyd, 2008), and typically privileged the functional aspects of a place. However, whilst the representational element of destinations and their re-generation remain important in communicating with diverse audiences, there is an increasing recognition of the importance of emotional and experiential benefits in driving preference and decisions (Chen \& Phou, 2013; Dickinger \& Lalicic, 2016; Murphy et al., 2007a). The functional attributes of tourist destinations alone are no longer viewed as sufficient to attract visitors. DMO's need to capitalise on and communicate the emotional attributes of their destination that are key to relationship building between visitors and a destination (Hultman et al., 2015). Taking this further, Bekk et al. (2016) note that whilst many holiday destinations may feature sea, sun, and sand, they can be differentiated from one another on the basis of characteristics such as glamour and luxury, and authentic and friendly. They also demonstrate that touristdestination personality similarity increases tourist' satisfaction and recommendations regarding the destination.

Personifying a place provides the opportunity to communicate its emotional attributes. Paxson (2009) and Brown and Campleo (2014) suggest that there is a long tradition of personifying place, in the form of, for example, naming streets and buildings after famous people, and describing the essence of a place using adjectives normally ascribed to people 
(e.g. 'smart' cities, 'happy' cities). Lakoff and Johnson (2008) define personification as a process whereby inanimate objects, institutions, abstractions, or substance are regarded as people, and have human characteristics attributed to them. Destination personality occurs when a DMO describes a set of human characteristics that tourists associate with the destination in their brand communications (Hosany et al., 2006). Aaker (1997) defined brand personality as the "set of human characteristics associated with a brand" (p. 347). Azoulay and Kapferer (2003) offer a more recent definition: "brand personality is the set of human personality traits that are both applicable to and relevant for brands" (p. 151). In offering this definition, Azoulay and Kapferer (2003) operationalise the notion of brand personality and distinguish it from the personality of a person. Consistent with this, Aaker and Fournier (1995) suggest that it is important to recognise that in the context of destination marketing, the term 'personality' does not literally reflect a person's appearance, traits, or behaviour, as in psychology, but is a metaphor that personifies destination attributes, benefits, price and users' imagery. Thus, in addition to personality characteristics, destination personality also includes socio-demographics, such as age and gender (Ekinci \& Hosany, 2006). In support of Aaker and Fournier (1995), Avis et al. (2012) assert that a more open interpretation of 'personality' can serve as a metaphor for intangible brand attributes; this may lead to the inclusion of traits that are not strictly human personality traits, such as 'modern'. They further argue that there should be no constraints on the range of the terms used to communicate brand traits. Various authors have suggested that, if the unique personality traits of a place can be captured in brand communications, they can be used to differentiate one place from another (Ekinci \& Hosany, 2006; Kavaratzis \& Ashworth, 2005; Murphy, Moscardo \& Benckendorff, 2007b; Usakli \& Baloglu, 2011). In turn, this can influence the formation of 
strong emotional associations with a destination, and thereby increase travel intentions, satisfaction and destination loyalty (Chen \& Phou, 2013: Murphy et al., 2007b).

Self-congruity theory has been used by a number of researchers to explain the impact of DBP on visitors' intentions and behaviours with regard to destinations. Self-congruity theory proposes that consumption behaviour is influenced by the match between a consumer's selfconcept and their perception of a destination (Sirgy and Su, 2000). The greater the match between a tourism destination's visitor image and the consumer's self-concept, the more likely it is that the tourist will have a favourable attitude towards a destination, which, in turn, may influence their visiting intentions (Murphy et al., 2007a; Rojas-Mendez et al., 2013; Rojas-Mendez et al., 2015).

Despite the growing interest in DBP, most of this research explores perceived DBP, typically through consumer surveys and neglects the projected DBP. In support of the need for further research on projected personality, Pitt et al. (2007) note the limitations associated with a high reliance on consumer surveys, and promote the adoption of other approaches to understanding DBP. Research into this area has potential to offer insights into how DMOs are personifying their destination brand, either deliberately or sub-consciously, which, in turn might inform practice and research. DMOs typically manage, or work with their marketing agency to manage brand communications through a range of channels, including people, paper and digital. Only two prior studies have considered projected brand personality. Most recently and significantly, Kim and Lehto (2013)'s study compared the projected DBP as communicated through the official Korean tourism website, and the perceived DBP through a survey conducted amongst a sample of US travellers. Interestingly, they found significant discrepancies between the perceived and projected personalities. Whilst the KTO's effort to portray South Korea as a sincere and family-oriented destination with warm-hearted people 
and advanced technologies appeared to be successful, there was a marked discrepancy on the 'excitement' dimension. The KTO had been trying to cast South Korea as exciting, dynamic and energetic, but these qualities were not acknowledged by the US travellers. Finally, Pitt et al. (2007) analyse the website brand communications of ten African nations, using Aaker's personality dimensions. The procedure that they use, combining content and correspondence analysis, offers a means whereby tourism researchers and managers can explore and compare projected brand personalities.

\subsection{Destination brand personality measurement and scales}

One of the most important, yet most significant challenges regarding research and practice concerning DBP is the development of robust measurement scales. Indeed, the development of measurement scales has been the primary objective of a number of studies (Ekinci \& Hosany, 2006; Eckini, Sirakaya-Turk \& Baloglu, 2007; Pan et al., 2017; Xie \& Lee, 2013). The approach to measurement has been significantly influenced by Aaker's (1997) brand personality scale, which consists of five dimensions (sincerity, excitement, competence, sophistication and ruggedness) with fifteen sub-facets or traits. Aaker's brand personality scale has made a significant contribution to theory building in respect of brand personality and its effect on consumer behaviour. In respect of place branding, with the exception of Kaplan, Yurt, Guneri and Kurtulus (2010), all other DBP studies on cities have used Aaker's scale as their point of departure. The scale has dominated and guided scale use and development for the measurement of place brand personality (e.g. Apostopoulou \& Papadimitriou, 2015 (mid-sized cities in Greece); Bekk et al., 2016 (Fuerteventura); Dickinger \& Lalicic, 2016 (Vienna); Xie \& Lee, 2013 (Bejing)). 
Notwithstanding, there are various criticisms regarding the use of Aaker's scale which was developed for product brands. Firstly, there is disquiet about the relationship between Aaker's scale and the 'Big 5' personality traits, developed in the field of human psychology. More specifically, in mapping Aaker's dimensions to the 'Big 5' traits, Aaker's dimension of sincerity maps onto the traits of agreeableness and conscientiousness, excitement includes items such as sociality, energy and activity, as does extroversion. The remaining two of Aaker's dimensions, sophistication and ruggedness, do not relate to any of the 'Big 5' traits. Other concerns and debates centre around whether the scale measures brand personality or brand identity (Azoulay \& Kapferer, 2003); its generalisability, particularly for comparing or relative positioning of brands (Austin, Siguaw \& Mattila, 2003); and, its initial construction and testing (Geuens, Weijters \& Wulf, 2009).

Secondly, there is trepidation as to whether a brand personality scale developed for products is applicable or suitable for destination place brands in which physical, hedonic and symbolic elements are critical components of the tourist's overall travel experience (Huang, Gursoy \& Xu, 2014; Pan et al., 2017). Travellers' perceptions of these elements are likely to have a direct impact on how tourists perceive a destination's personality (Ekinci \& Hosany, 2006; Ekinci et al., 2007). Hence, it is not surprising that studies that have attempted to use Aaker's traditional scale in tourism contexts report additional dimensions with substantial variations. Additions include conviviality (Ekinci \& Hosany, 2006; Ekinci et al., 2007), outdoorsy, and upper class (Murphy et al., 2007b), vibrancy (Usakli \& Baloglu, 2011), cool, and trendy (Sahin \& Baloglu, 2011). On the other hand, some of Aaker's personality dimensions are not in evidence in some destination studies, even when this scale has been used. 
As a result of these concerns regarding Aaker's scale, some researchers have sought to develop their own scale. Many use an elicitation process similar to that adopted by Aaker (1997) to develop their own dimensions. For example, d'Astous and Boujbel (2007) generated their own scale through an elicitation process that covered 29 countries. This scale was tested through a survey of a convenience sample of French-Canadian residents of Montreal; the scale had the following personality dimensions, none of which are in Aaker's scale: agreeableness, wickedness, snobbism, assiduousness, conformity, and unobtrusiveness. Rojas-Mendez et al. (2013) also used a free elicitation process in order to identify personality traits and dimensions in their study of the USA from the perspective of the Chinese; they identify three dimensions, amicableness, resourcefulness and self-confidence, none of which are in Aaker's scale. Kumar and Nayak (2014) in their study of the DBP of India conducted an elicitation process to generate unique traits of the Indian personality, but supplemented these traits from the scales of Aaker (1997) and d'Astous and Boujbel (2007); they identified the following dimensions: courteousness, vibrancy, conformity, liveliness, viciousness, and tranquillity. Kaplan et al. (2010) also used a free elicitation process to generate a list of 87 personality traits; their list included excitement, competence, and ruggedness (already in Aaker's scale), but also introduced three new dimensions, viz, malignancy, conservatism, and peacefulness.

Other researchers have used a variety of approaches to place brand personality scale development. In a study of the relationship between the destination personality and the destination image of Dubai, Souiden, Ladhari and Chiadmi (2017), used a selection of traits from Aaker (1997). Pan et al. (2017) generated personality characteristics from travel reviews, supplementing these with items from Aaker (1997) and Kaplan et al. (2010). After data collection with mainland Chinese travellers, they identified the following factors: 
competence, sacredness, vibrancy, femininity, and excitement. However, it is important to observe, that in their scale development they were working with projected DBP, whilst in their survey they were collecting data on perceived DBP. Given the discrepancies that Kim and Lehto (2013) found between perceived and projected DBP, further reflection is necessary on scale development processes. Hanna and Rowley (2017, chapter 2) summarise the studies using place brand personality dimensions between 2006 and 2015, and identify 29 dimensions, with all of Aakers' dimensions being cited more than once (sincerity: 8; competence: 6; excitement: 6, sophistication: 4; and, ruggedness: 3), hence revealing a lack of consensus regarding DBP scales.

Other studies further suggest that it is unclear whether it is possible to create a generic DBP scale. There are a number of potential reasons for this. First, Kavaratzis and Hatch (2013) suggest that a single, static view of place identity cannot reflect the full complexity of the place identity, on account of the involvement of multiple stakeholders in the creation, development and ownership of the identity of the place (Kavaratzis, 2012). Second, there is a growing body of evidence, which points to the role of culture in influencing individual perceptions of destination personality (Sung \& Choi, 2010). Aaker, Benet-Martinez, and Garolera (2001) examined the influence of cultural variations on brand personalities, and found, for instance, different perceptions of the same brand between Japanese, Spanish and American consumers, as well as identifying new culturally specific personality dimensions (e.g. peacefulness for Japan and passion for Spain). In the context of DBP, Rojas-Mendez et al. (2013) found significant differences between American and Chinese customers' perceptions of the US brand personality. This echoes Sahin and Baloglu (2009)'s earlier study of visitors from various countries to Istanbul, which that perceptions of cognitive and overall image, and of brand personality of a place, differed between nationalities. From a 
slightly different perspective, there is also evidence that nation brand personality is dependent on the product being evaluated (Ishii \& Watanabe, 2015). Finally, and with significant implications for the value of some previous research, a few authors have found that the perspectives of destination personality or DBP varies depending on the respondents' relationship with the city. For example, Apostolopoulou and Papadimitriou (2015) studied the destination personality of Patras, a mid-sized city in Greece. They found differences between local residents, past visitors, and non-visitors in their perceptions of DBP. Whilst multiple views on the personality of a city do not preclude the development of a generic scale, they do suggest that the development of such a scale is likely to be complex and that such a scale may not emerge until there is a strong body of research around the notion of destination (and place) brand personality.

\subsection{Destination brand personality of cities}

The majority of studies on DBP's focus on countries or nations; a limited number of studies focus on cities; Table 1 provides a summary of these studies. Most of these studies cover only one city; exceptions are Hosany et al. (2006), Ekinic and Hosany (2006) and Kaplan et al. (2010). As identified above, whilst some scale dimension's feature in most of these studies (e.g. excitement, competence) there are significant variations in the number and nature of the dimensions in the scales. Most of these studies conduct a survey, usually with visitors; hence their focus is on perceived DBP. Only Sahin and Baloglu (2009) performed an analysis of brochures and websites (projected DBP). Dickinger and Lalici (2016) also undertake a content analysis, but they study tourist content on social media, which can be viewed as a reflection of both perceived and projected DBP. Finally, with the exception of Kaplan et al. (2010), all of these studies use Aaker's scale or an adaption of the scale. 
Overall, Table 1 demonstrates that there is a significant need for future research into the DBP of cities. Moreover, given the concerns over the applicability of Aaker's scale in measuring DBP, there may be benefits to be accrued from using an alternative approach. Hence, this study takes Kaplan et al. (2010)'s scale as its point of departure, given that the scale was developed for cities, and its application has not been further explored.

\subsection{Positioning}

Considering the challenges facing destinations, such as cities and tourist regions, and, in particular, the concerns expressed about destination substitutability (Pike \& Ryan, 2004; Usakli \& Bagoglu, 2011; Zenker, 2009), the body of research that explicitly focusses on positioning is very limited. Three studies do explore the positioning of European capital cities on the basis of brand equity, but not brand personality. Molina et al. (2017) explore the brand equity generated through online and offline media, Mikulic et al. (2016) examine the relationships between brand strategies and tourism intensity, and Gomez, Fernandez, Molina and Aranda (2018) conduct a survey to compare the brand equity of selected European capital cities. Hosany et al. (2006) and Ekinci and Hosany (2007), on the other hand, did survey participants views on the personality of European countries, but they were not explicitly comparing destinations, but rather using a range of destinations to investigate the relationship between destination image and destination personality, and to develop a three-dimensional scale of DBP (sincerity, excitement, and conviviality).

The six studies that have considered the relative positioning of destinations on the basis of DBP have studied nations. Five focused on perceived DBP. d'Astous and Boujbel (2007) conducted a survey amongst French-speaking Canadians. They report on the mean position of each country with regard to each of their personality dimensions. On this basis, Australia and 
Mexico were perceived to be most associated with agreeableness, the United States with wickedness, France with snobbism, Japan with assiduousness, China with conformity, and Canada with unobtrusiveness. In a parallel study, d'Astous and Li (2009) adapted their scale to the Chinese cultural context and used it to position eleven countries, nine of which were the same as in their previous study. However, the association of specific dimensions with specific countries differed considerably from the results of the previous study, highlighting the importance of culture on perceptions of DBP. For example, in this study, China had the highest rating for agreeableness and assiduousness, Japan for wickedness, United States for snobbism, and Saudi Arabia for conformity and unobtrusiveness. Kim et al. (2013) conducted a survey of students in various countries; they suggest that the United States and Japan are positioned on leadership, Italy and Sweden on sophistication, Singapore and Sweden on peacefulness, and Korea on tradition. Matzler, Strobl, Stokburger-sauer, Bobvnicky and Bauer (2016) study the role of cultural differences on the impact of brand personality perceptions of tourists' visit intentions. Although their focus was on the congruity-visit intention relationship, they demonstrated difference on the effect of brand personality dimensions and brand self-congruity and visit intention between countries. Finally, Ishii and Watanabe (2015) undertook a survey in Japan in order to investigate the relationship between nation brand personality and product evaluation among Japanese people. Although not its primary output, this study developed a DBP scale with the three dimensions, sincerity, competence and warmth, and used this to profile attitudes towards products from different countries. Germany scored highest on sincerity, United States highest on competence, and Italy highest on warmth. Although no country was positively perceived on all dimensions, China was negatively perceived on all dimensions. 
Pitt et al. (2007) conducted the only study focussing on projected DBP, through a combination of content and correspondence analysis. Although the central purpose of this study was to demonstrate a method of researching destination positioning, Pitt et al. (2007) offers some interesting insights into the positioning of ten African countries. They observed three country groupings amongst the websites, one for Angola and South Africa, a second for Morocco, Swaziland, Ghana, Zambia, and Botswana, and a third group for Kenya and Zimbabwe; Malawi (not communicating any of the dimensions clearly) stood on its own.

It is important to observe that the studies discussed in this section use different sets of personality dimensions and/or traits and that none of these studies explore the DBP positioning of cities. This is a major weakness in the study of DBP, and more widely, place brand personality as will be discussed in the following section.

\section{Methodology}

To develop a projected DBP scale for European capital cities, this study collected and analyzed text-based content from the websites of ten European capital cities. This was followed by correspondence analysis of the DBP's of the cities as a basis for the exploration of the relative positioning of these cities based on their DBP dimensions. The data collection and analysis was facilitated through the use of QDA Miner with WordStat (Provalis Research, 2014)

\subsection{Data Collection}

The cities included in this study were selected based on the number of international visitors to their respective countries, according to the World Tourism Organization's Tourism Highlights (2016) (http://mkt.unwto.org/publications). This was the most recent, authoritative 
and comprehensive list of visitor statistics to European cities available when the research was being designed. The capital cities of the top ten most visited countries were selected for inclusion in this study. Other criteria for inclusion were that: (1) the city has an official tourism website, accessible in English; (2) the city website included rich textual data describing the city and, was not entirely dedicated to practical information for visitors. The selected websites were identified through a Google search. Where more than one candidate website was identified, the website for inclusion was selected on the basis of their URL and the organization identified as being responsible for the website.

Ten cities were deemed to be sufficient since other studies that have explored the DBP of either nations or cities have included ten or less in their study (e.g. d'Astous \& Li, 2009 (9 nations); de Rosa, Bocci \& Dryjanska, 2017 (10 cities); Ishii \& Wantanabe, 2015 (5 nations); Kaplan et al., 2010 (3 cities); Kim et al., 2013 (9 nations); Rojas-Mendez et al., 2013 (2 nations)). Additionally, analysis of more than ten cities can make the correspondence map very busy and therefore difficult to interpret (Pitt et al., 2007). Table 2 presents the ten European capital cities selected, together with the number of tourist arrivals to their country, website address, and the number of words mined from the website for content analysis.

A major challenge associated with extracting data from websites for subsequent content analysis is deciding which content to mine. The decision was made to focus on text-based information, in full acknowledgement that tourism websites also include many images, which are also important in communicating the personality of a destination. For the purpose of this study, textual elements include headlines and bodies of text that consist of a single sentence, a paragraph or several paragraphs (Brugger, 2009). To build the data set, text was mined from all levels in the hierarchy of each city website. However, any textual information relating to the practicalities of being in the city such as hotel reservations, transport links, addresses, 
opening times, weather forecasts, city maps, discounts, special offers and the like, was omitted from the data set. After selection, textual information for each city's website was converted into an analyzable format. That is, all textual information from each of the ten websites was copied into individual word documents pertaining to each capital city.

\subsection{Data analysis}

Content and correspondence analysis were used to analyze the text datasets for each city. Content analysis was used to profile the DBP for each city, whilst correspondence analysis was used to analyze the relative positioning of the cities based on their DBP's.

According to Bryman (2011), content analysis is "an approach to the analysis of documents and texts that seeks to quantify content in terms of predetermined categories and in a systematic and replicable manner" (p. 291). Whilst there is increasing interest in the content analysis of websites and social media sites by researchers for analyzing the messages communicated by organization's (Cormany \& Baloglu, 2011; Govers \& Go, 2005), it is important to acknowledge that content is not specifically designed for the generation of research findings, and, as such, this approach has limitations.

The first step in data analysis was the compilation of a synonym dictionary for Kaplan et al. (2010)'s place brand personality scale, consisting of six dimension and 87 personality traits. The six place brand personality dimensions with their respective number of traits are: excitement (31), malignancy (22), peacefulness (14), competence (7), conservatism (6), and ruggedness (7). Using Thesaurus.com, a product of Dictionary.com, synonyms were identified for the six dimensions and their associated traits. Only synonyms that had been identified by both researchers were selected. This process generated a final list of 2,044 synonyms. These were categorized according to Kaplan et al. (2010)'s dimensions and the 
synonym dictionary was entered into WordStat. Using WordStat's exclusion function, words with low semantic value such as conjunctions and pronouns were excluded from the dictionary.

Secondly, we imported the Word documents of the text derived from our ten city websites into WordStat, and selected the option 'Content Analyze', to load the text into QDA Minor. QDA Minor then produced contingency tables for each city showing brand personality dimensions and traits for each city website, on the basis of Kaplan et al. (2010)'s dimensions. Next, in order to create a scale that encompassed all of the European cities, the five most cited traits for each of Kaplan et al. (2010)'s personality dimensions were identified.

Finally, correspondence analysis was used to explore the relative positioning of the cities based on their personality dimensions. Correspondence analysis is a statistical technique that provides a graphical representation of cross tabulations or contingency tables that is converted into a joint space map by decomposing the chi-square statistic of the frequency matrix (Bendixen, 1995; Greenacre, 2016; Sourial et al., 2010). Correspondence analysis is suitable for exploratory data analysis (Hoffman \& Franke, 1986; Whitlark \& Smith, 2001). Using QDA Minor, a correspondence map showing the positioning of the ten cities was produced. 


\begin{tabular}{|c|c|c|c|c|}
\hline Author(s)/Title & Destination(s) Studied & Sample & Method & DBP Dimensions Found \\
\hline $\begin{array}{l}\text { Dickinger and Lalicic } \\
(2016)\end{array}$ & Vienna (Austria) & $\begin{array}{l}\text { International visitors, } \\
\text { Trip advisor user } \\
\text { generated content }\end{array}$ & $\begin{array}{l}\text { Survey } \\
\text { Content analysis of social } \\
\text { media }\end{array}$ & $\begin{array}{l}\text { Excitement, sincerity, sophistication, competence, } \\
\text { ruggedness }\end{array}$ \\
\hline $\begin{array}{l}\text { Apostolopoulou and } \\
\text { Papadimitriou (2015) }\end{array}$ & Patras (Greece) & $\begin{array}{l}\text { Local residents, past } \\
\text { visitors, non-visitors }\end{array}$ & $\begin{array}{l}\text { Elicitation } \\
\text { Survey }\end{array}$ & Excitement, sincerity \\
\hline $\begin{array}{l}\text { Sahin and Baloglu } \\
\text { (2014) }\end{array}$ & Istanbul (Turkey) & First-time visitors & $\begin{array}{l}\text { Content analysis of } \\
\text { brochures and websites } \\
\text { Survey }\end{array}$ & $\begin{array}{l}\text { Significant variable(s) based on purpose: } \\
\text { Relaxation - cognitive, Fun/excitement - personality, } \\
\text { Experience new things - affective image and } \\
\text { personality. }\end{array}$ \\
\hline $\begin{array}{l}\text { Papadimitriou, } \\
\text { Apostolopoulou, and } \\
\text { Kaplanidou (2013) } \\
\text { Xie and Lee (2013) }\end{array}$ & Athens (Greece) & Foreign tourists & Survey & Excitement, sophistication, competence, ruggedness. \\
\hline Kaplan et al. (2010) & $\begin{array}{l}\text { Istanbul, Ankara, Izmir } \\
\text { (Turkey) }\end{array}$ & College students & $\begin{array}{l}\text { Elicitation } \\
\text { Survey }\end{array}$ & $\begin{array}{l}\text { Excitement, competence, ruggedness, malignancy, } \\
\text { conservatism, peacefulness, }\end{array}$ \\
\hline $\begin{array}{l}\text { Hosany, Ekinci, and } \\
\text { Uysal (2006) }\end{array}$ & 3 unspecified UK cities & British nationals & Survey & Excitement, sincerity, conviviality \\
\hline $\begin{array}{l}\text { Ekinic and Hosany } \\
\text { (2006) }\end{array}$ & $\begin{array}{l}\text { Various destinations } \\
\text { European cities }\end{array}$ & British travellers & Survey & Excitement, sincerity, conviviality \\
\hline
\end{tabular}

Table 1: Studies on the destination brand personality of cities 


\begin{tabular}{|c|c|c|c|c|}
\hline \multicolumn{2}{|c|}{ European Capital City } & \multirow{2}{*}{$\begin{array}{l}\text { Tourist Arrivals } \\
\text { to the Country } \\
84,452\end{array}$} & \multirow{2}{*}{$\begin{array}{l}\text { Official Website } \\
\text { www.visitparisregion.com - Paris Convention and Visitor Bureau }\end{array}$} & \multirow{2}{*}{$\begin{array}{l}\begin{array}{l}\text { Number of Words } \\
\text { mined from City } \\
\text { websites }\end{array} \\
125,945\end{array}$} \\
\hline $\mathbf{1}$ & Paris, France & & & \\
\hline 2 & Madrid, Spain & 68,215 & www.esmadrid.com/en - Tourism Board & 131,613 \\
\hline $\mathbf{3}$ & Rome, Italy & 50,732 & www.turismoroma.it - Tourism Board & 123,093 \\
\hline 4 & Berlin, Germany & 34,972 & www.visitberlin.de - Tourism Board & 137,348 \\
\hline 5 & London, United Kingdom & 34,436 & www.visitlondon.com - Tourism Board & 81,421 \\
\hline 6 & Moscow, Russian Federation & 31,346 & www.moscow.info - Tourism Board & 36,341 \\
\hline 7 & Vienna, Austria & 26,719 & www.wien.info - Tourism Board & 100,398 \\
\hline 8 & Athens, Greece & 23,599 & $\underline{w w w . t h i s i s a t h e n s . o r g ~-~ A t h e n s ~ C o n v e n t i o n ~ a n d ~ V i s i t o r ~ B u r e a u ~}$ & 75,738 \\
\hline 9 & Warsaw, Poland & 16,728 & www.warsawtour.pl/en - Tourism Board & 37,482 \\
\hline 10 & Amsterdam, Netherlands & 15,007 & $\underline{\text { www.iamamsterdam.com }}$ - Amsterdam Convention Bureau & 61,694 \\
\hline
\end{tabular}

Table 2: Top ten European capital cities of most visited countries by rank order. 


\section{Findings}

\subsection{Scale development}

Based on the frequency of occurrence of each synonym under each trait for each city and in turn for each dimension, the top five traits under each dimension for each city were identified. The traits shown in Figure 1 are the top five traits in terms of frequency of occurrence in the dataset across all ten cities. The scale in Figure 1 has the same dimensions as in Kaplan et al. (2010)'s scale. The personality traits listed under the dimensions, however, differ from those in Kaplan's scale, because they have their origin in the synonym list developed for this research. 
Projected Destination Brand Personality Scale for European Capital Cities

\begin{tabular}{|c|c|c|c|c|c|}
\hline Competence & Conservatism & Excitement & Malignancy & Peacefulness & Ruggedness \\
\hline Leader & Villager & Elite & Shrewd & Sincere & Coward \\
\hline Mature & Poor & Popular & Respectable & Modern & Ruggedness \\
\hline Clever & Religious & Extraordinary & Self-seeking & Decent & Rough \\
\hline Reticent & Devout & Creative & Stingy & Tolerant & Rebellious \\
\hline Strong & Cool & Stylish & Barefaced & Peaceful & Harsh \\
\hline
\end{tabular}

Figure 1: The projected destination brand personality scale 


\subsection{The projected destination personalities of ten European capital cities}

The frequency of associations between each of the European capital cities and the brand personality dimensions is presented in Table 3 . Table 3 presents a number of findings. Firstly, it displays the total number of words in the dataset for each city. This is related to the size of the dataset, so comparing cities is difficult, however it is argued that cities with more words in the dataset, such as Paris, are being more proactive in communicating their DBP than those with fewer words in the dataset, such as Warsaw. Table 3 also presents the dimensions and their traits that occur most frequently in the combined dataset (total row). 'Excitement' is significantly more in evidence in projected personality than any of the other dimensions. That is, all ten cities want to communicate a sense of excitement to potential and actual visitors although some DMO's are more diligent than others. Other important dimensions are peacefulness, and competence, respectively.

Figure 2 presents the data in Table 3 in bar graph format. This has the advantage of displaying the level of occurrence for a specific dimension, as a percentage, of the total occurrences of dimensions for that city. In relation to Athens, for example, 'conservatism' has 188 incidences (Table 3) of the total incidences for all personality dimensions of 2462; the graph shows that for Athens, 'conservatism' contributes $8 \%$ to its projected DBP profile. Furthermore, the graph clearly shows that for every city 'excitement' constitutes a significant proportion of its projected DBP (from $45 \%$ to $66 \%$ ). It also shows which cities are being more proactive in communicating this dimension, with London, Amsterdam and Vienna taking the lead. The second most important dimension is 'peacefulness', which may be attributed to the relaxation and leisure that tourists often seek. Possibly consistent with its high ranking on excitement, London is the lowest city on peacefulness, with Madrid, Rome, Athens, Warsaw, and Moscow, respectively emphasizing peacefulness the most. Rankings of 
'competence', 'malignancy' and 'conservatism' are all relatively low suggesting that, whilst these DBP dimensions may feature more strongly in perceived DBP, these are not personality dimensions that places seek to promote. Finally, 'ruggedness' is very low for all cities; ruggedness is argued to be more likely associated with country and coastal locations. 


\begin{tabular}{rlllllll}
\hline \multicolumn{7}{c}{ European } & \multicolumn{7}{l}{ Destination Brand Personality Dimensions } & & & & \\
Capital City & Competence & Conservatism & Excitement & Malignancy & Peacefulness & Ruggedness & Total \\
\hline Paris & 355 & 154 & 2314 & 192 & 709 & 115 & 3839 \\
Madrid & 332 & 193 & 1689 & 174 & 729 & 81 & 3198 \\
Rome & 265 & 171 & 1460 & 203 & 662 & 81 & 2842 \\
Berlin & 368 & 146 & 1928 & 219 & 761 & 90 & 3512 \\
London & 332 & 93 & 2035 & 201 & 384 & 53 & 3098 \\
Moscow & 118 & 67 & 431 & 91 & 226 & 31 & 964 \\
Vienna & 239 & 90 & 1678 & 125 & 581 & 75 & 2788 \\
Athens & 245 & 188 & 1231 & 160 & 562 & 76 & 2462 \\
Warsaw & 82 & 93 & 454 & 85 & 217 & 23 & 954 \\
Amsterdam & 169 & 54 & 1110 & 109 & 341 & 32 & 1815 \\
Total & 2505 & 1249 & 14330 & 1559 & 5172 & 657 & $\mathbf{2 5 4 7 2}$ \\
\hline
\end{tabular}

Table 3: Distribution of destination brand personality dimensions 


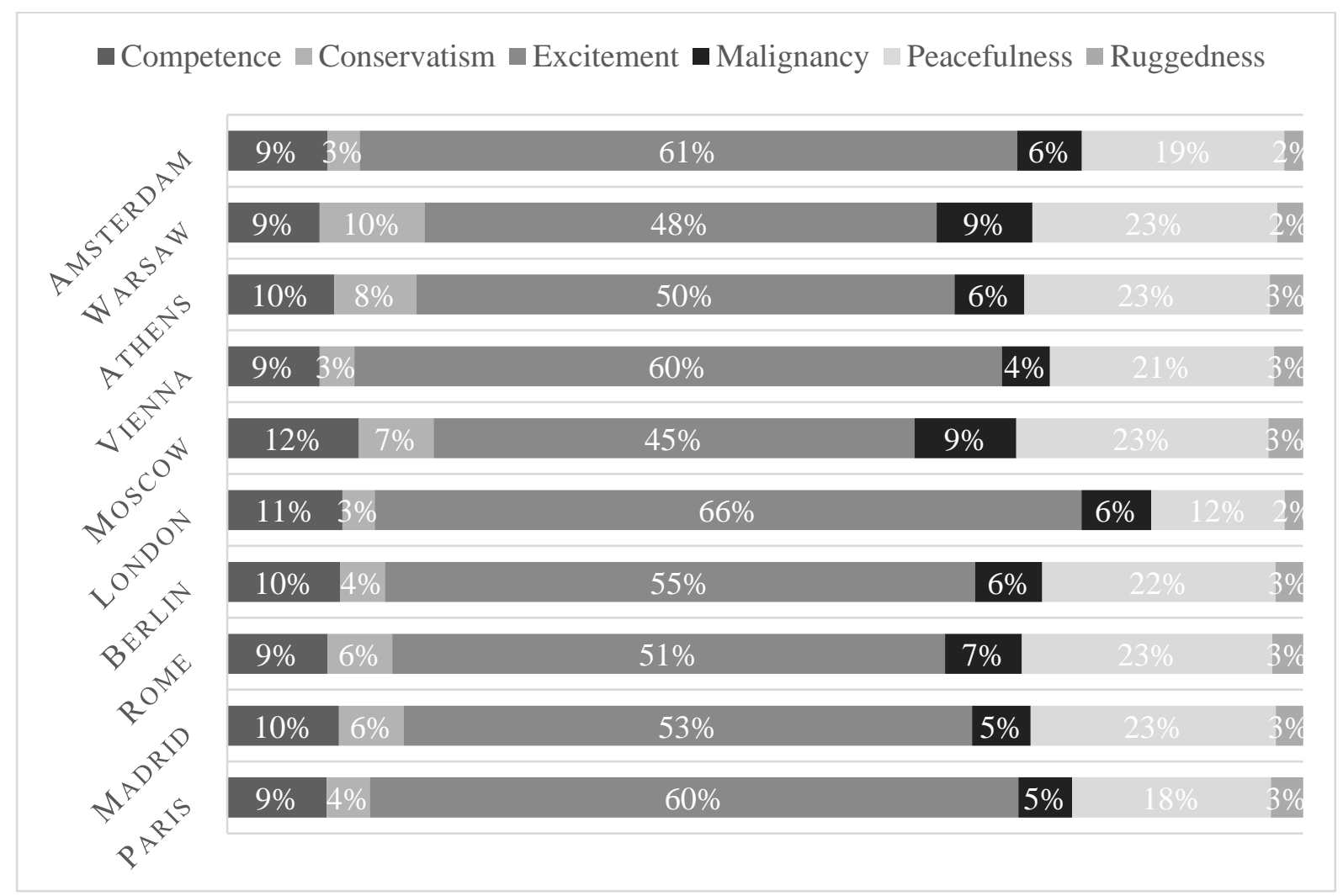

Figure 2: Relative frequency of destination brand personality dimensions for each European capital city 


\subsection{Correspondence analysis}

In support of the correspondence analysis, a chi-square test was conducted using the data in Table 3; the test confirms a significant association between destination brand personality dimensions and projected city destination personalities $\left(\chi^{2}, 561.5338 ; \mathrm{Df}, 45 ; \mathrm{P}<0.001\right)$.

The correspondence map (Figure 3) reveals the positioning of the city websites in relation to the DBP dimensions but also how the websites (columns) and the dimensions (rows) relate to each other (Sourial et al., 2010; Yelland, 2010). In order to determine the dimensionality of a correspondence map, the eigenvalues and the cumulative proportion explained by the dimensions must be examined (Greenacre, 2016; Hair, Black, Babin, Anderson \& Tatham, 2006). The cumulative proportion accounts for $91 \%$ of the total variance, with eigenvalues and explained proportions of 0.017 and 0.765 for the first dimension, and 0.003 and 0.144 for the second dimension respectively (Table 4). For ease of interpretation (Bendixen, 1995; Greenacre, 2016; Pitt et al., 2007; Sourial et al., 2010), a two-dimensional correspondence map is chosen to present the results (Figure 3). 


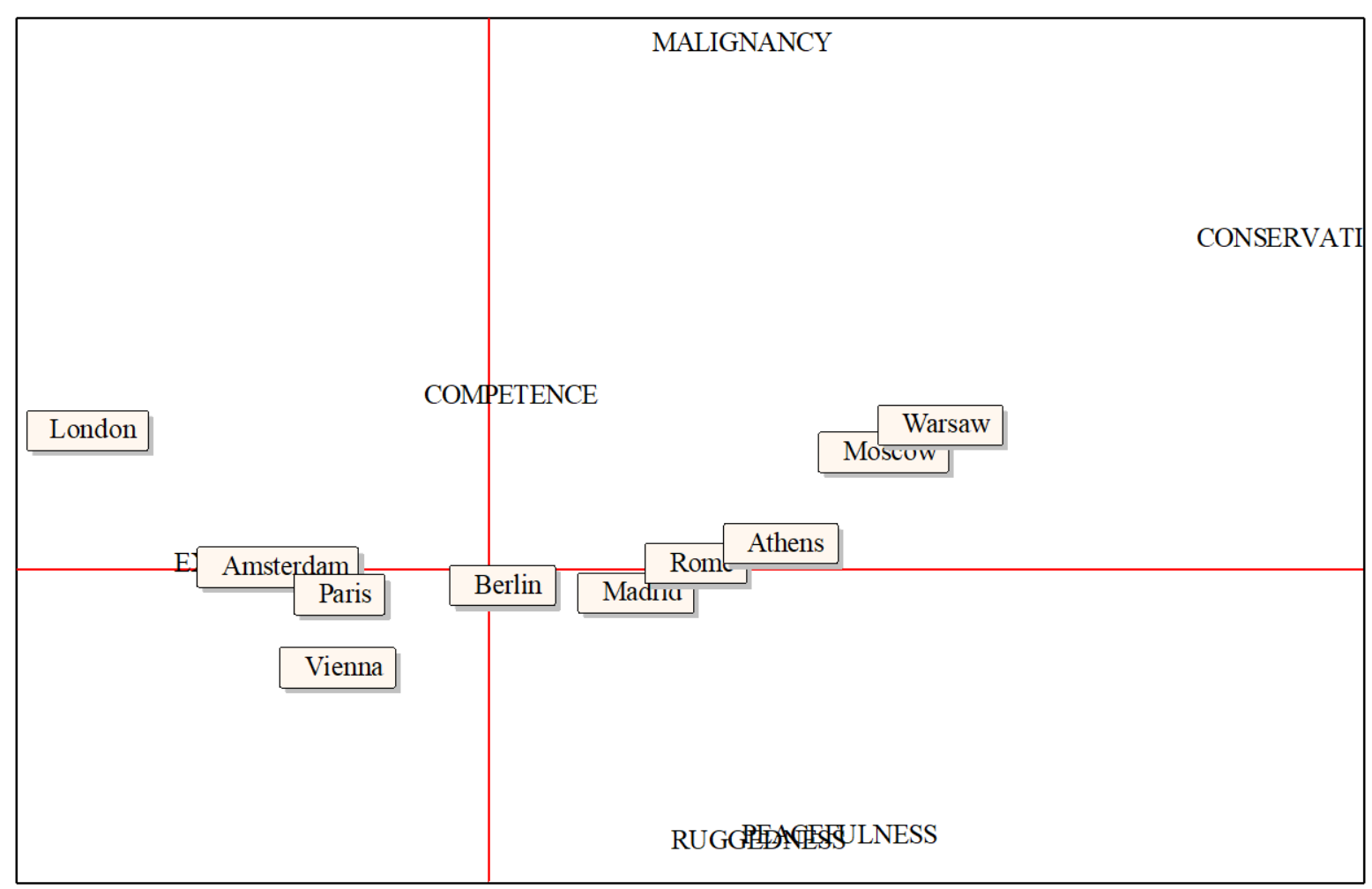

Figure 3: Correspondence analysis: map of ten European capital cities' projected DBP. The point of origin is where the axes meet. (Figure as presented in the output from QDA Miner) 


\begin{tabular}{|c|c|c|c|}
\hline \multicolumn{4}{|l|}{ Eigenvalues } \\
\hline Eigenvalues & Percentages & \multicolumn{2}{|c|}{ Cumulative \% } \\
\hline 0.017 & 76.500 & \multicolumn{2}{|l|}{76.500} \\
\hline 0.003 & 14.404 & \multicolumn{2}{|l|}{90.904} \\
\hline 0.001 & 5.163 & \multicolumn{2}{|l|}{96.067} \\
\hline \multicolumn{4}{|c|}{ Variable Coordinates } \\
\hline Item & Axis 1 & Axis 2 & Axis 3 \\
\hline Amsterdam & -0.114 & -0.007 & -0.026 \\
\hline Athens & 0.157 & 0.014 & 0.038 \\
\hline Berlin & 0.007 & -0.022 & -0.048 \\
\hline London & -0.217 & 0.104 & 0.004 \\
\hline Madrid & 0.079 & -0.027 & 0.008 \\
\hline Moscow & 0.213 & 0.087 & -0.089 \\
\hline Paris & -0.081 & -0.029 & 0.031 \\
\hline Rome & 0.111 & -0.004 & -0.012 \\
\hline Vienna & -0.082 & -0.088 & 0.008 \\
\hline Warsaw & 0.243 & 0.108 & 0.066 \\
\hline \multicolumn{4}{|c|}{ Words/Categories Coordinates } \\
\hline Item & Axis 1 & Axis 2 & Axis 3 \\
\hline Competence & 0.055 & 0.817 & -1.433 \\
\hline Conservatism & 2.637 & 1.582 & 3.004 \\
\hline Excitement & -0.776 & -0.010 & 0.375 \\
\hline Malignancy & 0.809 & 2.547 & -1.710 \\
\hline Peacefulness & 1.133 & -1.342 & -0.645 \\
\hline Ruggedness & 0.866 & -1.376 & 0.708 \\
\hline
\end{tabular}

Table 4: Correspondence analysis detail 
Figure 3 indicates a more similar distribution of synonyms among the dimensions of 'ruggedness' and 'peacefulness' relative to the total distribution of all synonyms within the dimensions. Equally, relative to all dimensions, 'malignancy' and 'conservatism' have distributions that are more singular in nature. In addition, the map reveals the similarities amongst projected city DBP with three clear groupings; Warsaw and Moscow (1), Athens, Rome and Madrid and potentially Berlin (2), and Amsterdam, Paris and Vienna (3). London's DBP stands alone. Further, on closer inspection, while Warsaw and Moscow have similarities, they along with London, are situated further away from their corresponding points of origin when compared to the entire sample of the websites.

However, when examining the relationships between the columns and rows, interpretation of the correspondence map should be made with caution given that columns and rows are scaled independently (Sourial et al., 2010; Yelland, 2010). For example, it is inaccurate to infer the prevalence of closeness between a city website (column) and personality dimension (row) based on their proximity on the correspondence map. Therefore, while the distance between the websites and the dimensions has no interpretable meaning, the simplest way to determine the strength of the relation is to draw a line from the categories corresponding points in the plot to the point of origin (Provalis Research, 2010; Yelland, 2010). If the angle between the two lines is 'acute', then the dimension occurs more often in the observed city website than it does on average in the whole sample. Conversely, if the angle is 'obtuse', the dimension occurs less often in relation to the observed city website than in the overall sample. Table 5 presents interpretation of the correspondence map, while Figure 4 provides a visual example of the interpretation with respect to Moscow and the dimensions of 'malignancy' and 'excitement'; it appears that the dimension of 'malignancy' occurs more often than average in Moscow, while 'excitement' occurs less often. 


\begin{tabular}{|c|c|c|c|c|c|c|c|c|c|c|c|c|}
\hline \multirow[b]{2}{*}{$\begin{array}{r}\text { European } \\
\text { Capital } \\
\text { City }\end{array}$} & \multicolumn{12}{|c|}{ Destination Brand Personality Dimensions } \\
\hline & 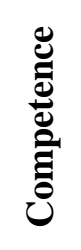 & 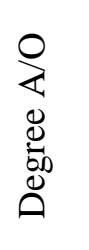 & 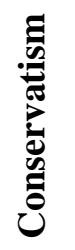 & 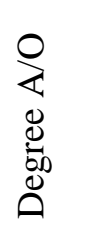 & 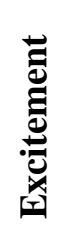 & 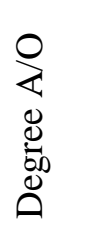 & 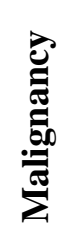 & 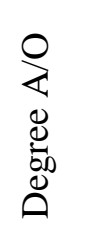 & 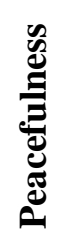 & 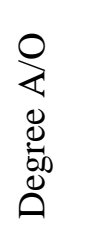 & 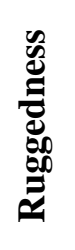 & 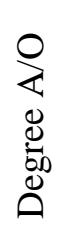 \\
\hline Paris & $\mathbf{O}$ & 110 & $\mathbf{O}$ & 170 & $\mathbf{A}$ & 15 & $\mathbf{O}$ & 130 & $\mathbf{O}$ & 130 & $\mathbf{O}$ & 120 \\
\hline Madrid & $\mathbf{O}$ & 93 & $\mathbf{A}$ & 35 & $\mathbf{O}$ & 170 & $\mathbf{A}$ & 80 & $\mathbf{A}$ & 30 & $\mathbf{A}$ & 35 \\
\hline Rome & $\mathbf{A}$ & 83 & $\mathbf{A}$ & 25 & $\mathbf{O}$ & 180 & $\mathbf{A}$ & 70 & $\mathbf{A}$ & 40 & $\mathbf{A}$ & 50 \\
\hline Berlin & $\mathbf{O}$ & 130 & $\mathbf{A}$ & 70 & $\mathbf{O}$ & 130 & $\mathbf{O}$ & 110 & $\mathbf{A}$ & 10 & $\overline{\mathbf{A}}$ & 5 \\
\hline London & $\mathbf{A}$ & 70 & O & 135 & $\mathbf{A}$ & 20 & $\mathbf{A}$ & 90 & $\mathbf{O}$ & 160 & O & 150 \\
\hline Moscow & $\mathbf{A}$ & 70 & $\mathbf{A}$ & 10 & $\mathbf{O}$ & 160 & $\mathbf{A}$ & 50 & $\mathbf{A}$ & 60 & $\mathbf{A}$ & 65 \\
\hline Vienna & $\mathbf{O}$ & 130 & $\mathbf{O}$ & 170 & $\mathbf{A}$ & 35 & $\mathbf{O}$ & 150 & $\mathbf{O}$ & 100 & $\mathbf{O}$ & 90 \\
\hline Athens & $\mathbf{A}$ & 80 & $\mathbf{A}$ & 20 & $\mathbf{O}$ & 185 & $\mathbf{A}$ & 60 & $\mathbf{A}$ & 40 & $\mathbf{A}$ & 55 \\
\hline Warsaw & $\overline{\mathbf{A}}$ & 65 & $\mathbf{A}$ & 5 & $\mathbf{O}$ & 160 & $\overline{\mathbf{A}}$ & 50 & $\overline{\mathbf{A}}$ & 60 & $\mathbf{A}$ & 70 \\
\hline Amsterdam & $\mathbf{O}$ & 100 & $\mathbf{O}$ & 150 & $\mathbf{A}$ & 9 & $\mathbf{O}$ & 115 & $\mathbf{O}$ & 140 & $\mathbf{O}$ & 130 \\
\hline
\end{tabular}

Table 5: $\mathrm{A}=$ acute, $\mathrm{O}=$ obtuse 


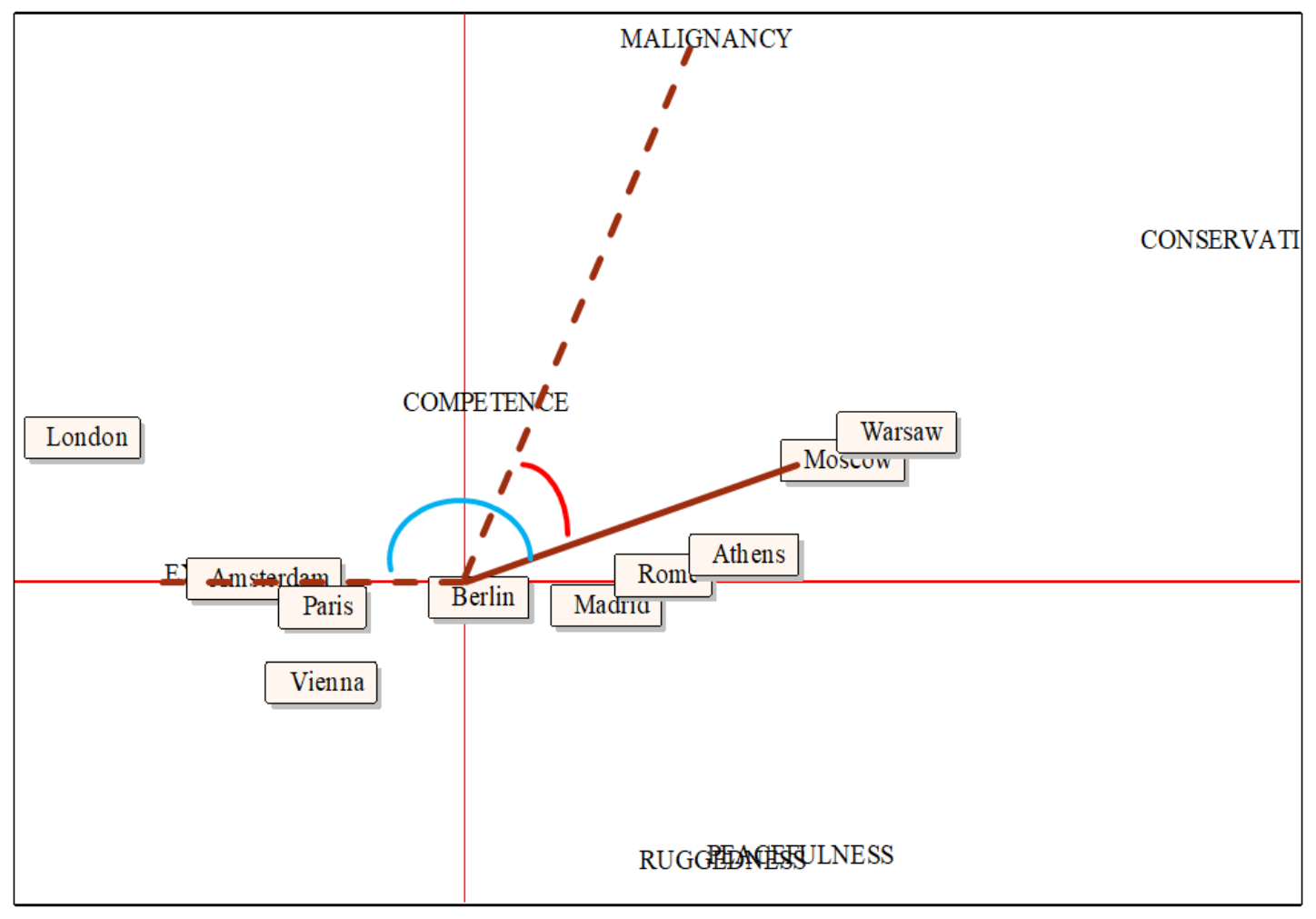

Figure 4: Visual example of the interpretation of the correspondence map.

\subsection{Interpretation of correspondence analysis and its exemplification}

The following comments on the findings from the correspondence analysis as reported in

Figure 3 and Table 6; interpretation of the results is dependent on whether the angle between the city website and the DBP is obtuse or acute, and on the size of these angles. Care needs to be taken in interpreting this data. For example, whilst Vienna is positioned closer to 'excitement' on the correspondence map, London has a stronger association with the dimension, as indicated by the smaller acute angle (Table 5). Interpretation is further supported with various illustrative comments from the city websites.

Amsterdam, Paris, London and Vienna's projected DBPs are more strongly associated with 'excitement' than those of the remaining cities. An examination of the content of these websites illustrates this summary to be a reasonable representation. Amsterdam is presented as a tourism destination with contemporary architecture and neighborhoods as cultural 
hotspots. For instance, Oots is "ethnically diverse and strikingly spacious...[it] is known for its wide streets lined by monumental...and...vibrant cultural mix", whilst Noord has "vast green expanses and charming little villages plus some of the city's most cutting-edge architecture, exciting festivals, artist studios and stylish waterside hangouts with beautiful terraces". Paris is portrayed as "futuristic, audacious and original". Its communications emphasise luxury, elegance and romance, in respect of the city's cuisine, fashion and architectural design. Similarly, the website for London communicates both the history, and the cosmopolitan nature of the city. For instance, "with its alternative vibe, Camden [town] is abuzz with famous markets, live music venues and street performers. Away from the bustle, there's also a picture-pretty canal and some gorgeous green spaces to explore", while the West End is “...this dazzling area [that] is home to spectacular shopping streets, a topnotch restaurant scene and a world-famous theatre district".

Rome, Athens, Madrid and Berlin are most strongly associated with 'peacefulness'. Arguably, because of their tumultuous pasts, all of these cities' websites are characterized by a strong grounding in history and culture and suggest an appreciation of the value of peace. Rome's DMO website presents the city's heritage in relation to each of its classical, archeological and religious landmarks; it looks back to a time when Rome was the capital of the known world, and acknowledges its role as the seat of the Catholic Church. Athens website boasts of "...historic walk[s] and...charming old-style neighborhoods, oases away from the hustle and bustle of the city center...". Finally, the website for Berlin acknowledges the city's rich, textured and tangible past; “...you can still sense Berlin's turbulent past at the city's many memorial sites along the Berlin Wall trail”, but also characterizes the city as a destination that embraces personal freedom and creativity. For instance, the district of 
Friedrichshain-Kreuzberg “...is not just the coolest in Berlin, but the hippest location in the entire universe..."

In relation to 'conservatism', Warsaw and Moscow are the strongest cities associated with this personality dimension. Moscow is portrayed as a traditional Russian city; it is " .... living museum to a millennium of political, religious and cultural history". The website demonstrates how the city's soviet past collides with its capitalist present and how the Orthodox Church has helped to define the city. Moscow's novel theatres have reclaimed leadership in the dramatic arts, and its traditional markets have been revived; the city continues to refurbish itself.

Finally, Madrid, Rome, Athens, Warsaw and Moscow, project interesting profiles in that relative to the other cities (excluding Berlin), they do not exhibit a strong association with 'excitement'. Furthermore, given that, they all have acute angles for the remaining dimensions, they do not communicate a personality that is more strongly aligned with one personality dimension. This could be regarded as a strength or a weakness. Given that people typically have a range of personality traits, and the extent to which one or more of those traits dominates varies between individuals, destinations that have a more balanced appeal, may also find a position in the marketplace.

\section{Discussion and Conclusions}

\subsection{Implications for theory}

There is increasing evidence that an alignment between a visitor's personality, and DBP has a significant impact on intentions to purchase products, travel to and develop ties with a place (Murphy et al., 2007a; Rojas-Mendez et al., 2013; Rojas-Mendez et al., 2015; Usakli \& Balogulu, 2011). This evidence has fuelled interest in understanding the nature of destination 
personality, and how that personality can be captured and communicated in the destination branding process. However, there are a number of gaps in theory development and testing in the realm of DBP. The most significant of these are discussed below.

\subsubsection{Developing a projected destination brand personality scale}

A key challenge is the development of one or more measurement scales for DBP.

Researchers have approached the development of measurement scales using various methods, with most adopting or adapting Aaker's scale for product brand personality (e.g. Bekk et al., 2015; Dickinger \& Lalicic, 2016). However, there is a lively critique in the literature (e.g. Huang et al., 2014; Pan et al., 2017) that suggests that a scale that was originally proposed for product brands is unsuitable for capturing the multi-facetted personality of a place or destination. Others have developed their own scale, based on an initial elicitation process (e.g. Kaplan et al., 2010; Kumar \& Nayak, 2014; Rojas-Mendez et al., 2013) but with considerable variation in the scales generated. This variation may result from the differing nature and culture (Kim \& Stepchenkova, 2017; Matzler et al., 2016; Sung \& Choi, 2010) of the destinations studied, the respondents, or the research process. Additionally, with the exception of studies that have used Aaker's scale, there is a limited number of studies that have sought to replicate scales (Apostopoulou \& Papadimitriou, 2015; Kumar \& Nayak, 2014; Upadhyya, 2012). Indeed, those using scales other than Aaker's, have adopted a range of different scales (d'Astous \& Boujbel, 2007; Kaplan et al., 2010; Kuma \& Nyak, 2014; Pike 2009; Rojas-Mendez et al., 2013). Hence, it would appear that further research is needed to establish whether it is possible to develop a generic scale, and if so, to establish its dimensions and traits. Accordingly, this research, whilst grounded on the practice of other researchers (e.g. Kumar \& Nayak, 2014: Rojas-Mendez et al., 2013), uses the only other scale 
developed for cities, Kaplan et al. (2010)'s scale as a point of departure, and demonstrates the transferability of Kaplan et al. (2010)'s dimensions to a different context. It is noted, however, that the traits identified by Kaplan et al. (2010) and those identified in this study differ, possibly due to the nature and cultural backgrounds of the cities studied.

Arguably however, the most important distinction is that this study focusses on projected DBP, whereas Kaplan et al. (2010), in common with most other researchers, explore perceived DBP (e.g. Hosany et al., 2006; Kim et al., 2013). One of the two studies to examine projected DBP, Kim and Lehto (2013), found significant differences between the projected DBP (as communicated through official tourism websites), and the perceived DBP based on a survey.

\subsubsection{Profiling the relative positioning of destination brand personalities}

One of the primary purposes of destination branding is to ensure that the destination's identity is communicated in a competitive marketplace, in which destination substitutability presents a significant challenge (Usakli \& Baloglu, 2011). Hence, it is not sufficient to be able to characterize and communicate a destination's personality. It is also essential to be able to manage its positioning relative to other destinations. Given the importance of understanding DBP positioning, the body of research in this field is surprisingly limited. Only six studies have considered the relative positioning of destinations on the basis of DBP to varying extents and from various angles; all have studied the positioning of nations, of which five have focused on perceived DBP (e.g. d'Astous \& Boujbel, 2007; Ishii and Watanabe, 2015; Kim et al., 2013). Only Pitt et al. (2007) undertook a study that focussed on projected DBP and positioning, studying this for ten African countries using content and correspondence analysis. Given the importance of measuring projected DBP, and of 
positioning, and the paucity of studies of these topics, this research makes a significant contribution by demonstrating the value of the approach adopted by Pitt et al. (2007).

\subsection{Implications for management}

There is no research on whether DMO's are consciously intending to communicate a specific and distinct destination brand personality. In addition, it may be that they do not all have a planned branding strategy, and it is certainly the case that investment in destination branding will vary between cities. If (as it should be) (Hanna \& Rowley, 2011), it is the DMO's intention to strategically communicate a distinct DBP, then a projected DBP scale can assist DMO's by increasing their awareness of the personality dimensions and traits embedded in their communications through various digital channels, including websites and social media. In addition, the application of a projected DBP scale would support DMO's in monitoring and managing their projected personality over time, and exploring the consistency of the projected DBP through different channels, including social media those in which the voices of visitors, residents, businesses, and other stakeholders might predominate. Indeed, Kendall and Gursoy (2007) suggest that since projected DBP data is relatively easy and inexpensive to gather, efficiencies in the processes associated with assessing the positioning of destinations can be achieved through analysing DBP's of competitor destinations. Finally, it would be beneficial for stakeholders, DMO's and academics to collaborate in exploring best practice regarding approaches to the measurement or assessment of the relationship between perceived and projected DBP for specific cities and other destinations.

For managers, this research also draws attention to the issue of the positioning of destinations, relative to potential competitor destinations. More specifically, for capital cities, an analysis of their projected personality relative to that of other destinations, could inform 
strategic development and investment, leading to a more coherent and stronger identity, reenforced by more focussed communication. On the other hand, it is important to acknowledge that changing a DBP is likely to be a lengthy process, with many political nuances, since DMO's are accountable to a diverse range of publics and stakeholders (Pike, 2009). However, importantly, the use of correspondence maps is a reminder that no destination (or product, organisation or person) positions itself on only one dimension, but rather combines elements of different dimensions, with some being more central to their identity than others are, but all are contributing to the destination's success.

\subsection{Limitations and further research}

This study has widened the ongoing debate regarding the development of a measurement scale for destination and place brand personality. The study offers an insight into projected DBP based on European cities using Kaplan et al. (2010)'s rather than Aaker's (1997) scale, however it has not resolved the issues associated with the measurement of DBP. Hence, there is considerable scope for further research into the measurement of DBP, including scale development(s) and their applicability in different contexts (e.g. tourism, product evaluation) and cultures. Particularly pressing is research into projected DBP, given the increasing use of digital platforms, including social media, by both DMO's and travellers, to communicate the essence of destinations. A further interesting line of investigation would be the role of images and moving images in communicating the projected DBP.

In addition, this research has contributed to exploring approaches for positioning destinations on the basis of their DBP. In this context, it has also demonstrated the application and value of correspondence analysis. Notwithstanding, there is significant scope for further research in relation to the positioning of various destinations such as coastal 
regions, tourist attractions, winter sports venues, and districts within cities. Moreover, research on profiling destination personality that explores the role of culture in the formulation of both projected and perceived DBP, as well as on the relative positioning of perceived vs projected DBP is needed. This should include further research into the nature and roles of self-congruity in people's responses to destinations and places. It would also be beneficial to undertake investigations with DMO's that explore their view on the importance of DBP in marketing communications, including their notions of dimensions and traits, and of relative positioning.

Finally, there is an emerging body of research into the role of social media in destination branding. Whilst this is beyond the scope of this study, it is an important consideration for further research. For example, building on de Rosa et al. (2017)'s research that compares the communicative capacity of DMO websites with forum discussion on TripAdvisor, there is scope for further exploration of the relationship between the projected DBP's of DMO communication and peer traveller communication. Dickinger and Lalicic (2016) compare the outcomes of content analysis of Trip Advisor reviews and a survey that explored the DBP of Vienna. Interestingly, the dimensions of excitement, sophistication and ruggedness were much more strongly represented in tourist's comments on Trip Advisor, than they were in the survey. Going forward, research into DBP must not only consider scales, perceived and projected DBP, and positioning, but also the variety of channels and players.

\section{References}

Aaker, J. L. (1997). Dimensions of brand personality. Journal of Marketing Research, 34(3), 347-356. 
Aaker, J., \& Fournier, S. (1995). A brand as a character, a partner and a person: three perspectives on the question of brand personality. Advances in Consumer Research, 22, 391-395.

Aaker, J. L., Benet-Martinez, V., \& Garolera, J. (2001). Consumption symbols as carriers of culture: a study of Japanese and Spanish brand personality constructs. Journal of Personality \& Social Psychology, 81, 492-508.

Ahuvia, A. C. (2005). Beyond the extended self: loved objects and consumers' identity narratives. Journal of Consumer Research, 32(1), 171-184.

Anholt, S. (2005). Editorial: some important distinctions in place branding. Place Branding, 1(2), 116-121.

Apostolopoulou, A., \& Papadimitriou, D. (2015). The role of destination personality in predicting tourist behavior: implications for branding mid-sized urban destinations. Current Issues in Tourism, 18, 1132-1151.

Austin, J. R., Siguaw, J. A., \& Mattila, A. S. (2003). A re-examination of the generalizability of the Aaker brand personality measurement framework. Journal of Strategic Marketing, 11, 77-92.

Avis, M., Aitken, R., \& Ferguson, S. (2012). Brand relationship and personality theory: metaphor or consumer perceptual reality. Marketing Theory, 12, 311-331.

Azoulay, A., \& Kapferer, J. N. (2003). Do brand personality scales really measure brand personality? The Journal of Brand Management, 11, 143-155.

Baloglu, A., Henthorne, T. L., \& Sahin S. (2014). Destination image and brand personality of Jamaica: a model of tourist behavior. Journal of Travel \& Tourism Marketing, 31, 10571070. 
Belk, R. (1988). Possessions and the extended self. Journal of Consumer Research, 15(2), 139-168.

Bekk, M., Sporrle, M., \& Kruse, J. (2016). The benefits of similarity between tourist and destination personality. Journal of Travel Research, 55, 1008-1021.

Bendixen, M. (1995). Composing perceptual mapping using chi-squared trees analysis and correspondence analysis. Journal of Marketing Management, 11(6), 571-581.

Blain, C., Levy, S. E., \& Ritchie, J. R. B. (2005). Destination branding: insights and practices from destination management organisations. Journal of Travel Research, 43, 328-338.

Brown, S., \& Campelo, A. (2014). Do cities have broad shoulders? Does Motown need a haircut? On urban branding and the personification of place. Journal of Macromarketing, $34,421-434$

Brugger, N. (2009). Website history and the website as an object of study. New Media and Society, 11(1-2), 115-132.

Bryman, A., \& Bell, E. (2011). Business Research Methods. $3^{\text {rd }}(\mathrm{Ed})$., Oxford, UK: Oxford University Press.

Chen, C.F., \& Phou, S. (2013). A closer look at destinations: image, personality, relationship and loyalty. Tourism Management, 36, 269-278.

Cormany, D., \& Baloglu, S. (2011). Medical travel facilitator websites: an exploratory study of web page contents and service offered to the prospective medical tourist. Tourism Management, 32, 709-716.

d'Astous, A., \& Boujbel, L. (2007). Positioning countries on personality dimensions: Scale development and implications for country marketing. Journal of Business Research, 60, 231-239. 
d'Astous, A., \& Li, D. (2009). Perceptions of countries based on personality traits: a study of China. Asia Pacific Journal of Marketing and Logistics, 21, 475-488.

de Rosa, A.S., E. Bocci, \& Dryjanska, L. (2017). Social representation of the European capitals and destination e-branding via multi-channel web communication. Journal of Destination Marketing \& Management. Advance online publication. https://doi.org/10.1016/j.jdmm.2017.05.004

Dickinger, A., \& Lalicic, L. (2016). An analysis of destination brand personality and emotions: a comparison study. Information Technology \& Tourism, 15, 317-340.

Ekinci, Y., \& Hosany, S. (2006). Destination personality: an application of brand personality to tourism destinations. Journal of Travel Research, 45, 127-139.

Ekinci, Y., Sirakaya-Turk, E., \& Baloglu, S. (2007). Host image and destination personality. Tourism Analysis, 12, 433-446.

Geuens, M., Weijters, B., \& De Wulf, K. (2009). A new measure of brand personality. International Journal of Research in Marketing, 26, 97-107.

Gomez, M., Fernandez, A.C., Molina, A., \& Aranda, E. (2018). City branding in European capitals: an analysis from the visitor perspective. Journal of Destination Marketing \& Management, 7, 190-201.

Gospodini, A. (2002). European cities in competition and the new 'uses' of urban design. Journal of Urban Design, 7(1), pp.59-73.

Gospodini, A. (2004). Urban morphology and place identity in European cities: built heritage and innovative design. Journal of Urban Design, 9(2), 225-248.

Govers, R. \& Go, F. M. (2005). Projected destination image online: website content analysis of pictures and text. Information Technology \& Tourism, 7, 73-89.

Greenacre, M. (2016). Correspondence analysis in practice. $3^{\text {rd }}$ (Ed.), CRC press. 
Guerreiro, M., Agapito, D., \& Pech, M. (2015). Exploring the personality traits of Portugal as a tourist destination: perspective of the Czech market. Journal of Spatial \& Organizational Dynamics, 3, 114-124.

Hair, J., Black, W., Babin, B., Anderson, R., \& Tatham, R. (2006). Multivariate Data Analysis. $6^{\text {th }}$ (Ed.), Prentice-Hall, Upper Saddle River, NJ.

Hanna, S. \& Rowley, J. (2011). Towards a strategic place brand management model. Journal of Marketing Management, 27, 458-476.

Hanna, S. \& Rowley, J. (2017). Do places have a personality? In A. Bayraktar and C. Uslay (Eds.), Strategic Place Brand Methodologies and Theory for Tourist Attractions (pp. 2141). IGI-Global.

Hoffman, D. L., \& Franke, G. R. (1986). Correspondence analysis: graphical representation of categorical data in marketing research. Journal of Marketing Research, 23, 213-227.

Hosany, S., Ekinci, Y., \& Uysal, M. (2006). Destination image and destination personality: an application of branding theories to tourism places. Journal of Business Research, 59, 638-642.

Huang, L., Gursoy, D., \& Xu, H. (2014). Impact of personality traits and involvement on prior knowledge. Annals of Tourism Research, 48, 42-57.

Hultman, M., Skarmeas, D., Oghazi, P., \& Beheshti, H. M. (2015). Achieving tourist loyalty through destination personality, satisfaction and identification. Journal of Business Research, 68, 2227-2231.

Ishii, K., \& Watanabe, S. (2015). Nation brand personality and product evaluation among Japanese people: implications for nation branding. Place Branding \& Public Diplomacy, $11,51-64$. 
Kaplan, D., M., Yurt, O., Guneri, B., \& Kurtulus, K. (2010). Branding places: applying brand personality concept to cities. European Journal of Marketing, 44, 1286-1304.

Kavaratzis, M. (2004). From city marketing to city branding: towards a theoretical framework for developing city brands. Place Branding \& Public Diplomacy, 1(1), 58-73.

Kavaratzis, M. (2012). From 'necessary evil' to necessity: stakeholders' involvement in place branding. Journal of Place Management \& Development, 5(1), 7-19.

Kavaratzis, M., \& Ashworth, G. J. (2005). City branding: an effective assertion of identity or a transitory marketing trick? Tijdschrift voor economische en sociale geografie, 96, 506514.

Kavaratzis, M., \& Hatch, M. J. (2013). The dynamics of place brands an identity-based approach to place branding theory. Marketing Theory, 13, 69-86.

Kendall, K.W., \& Gursoy, D. (2007). A managerial approach to positioning and branding: eponymus or efficient. Tourism Analysis, 12, 473-483.

Kim, Y. K., Shim, S. W., \& Dinnie, K. (2013). The dimensions of nation brand personality: a study of nine countries. Corporate Reputation Review, 16, 34-47.

Kim, H-B., \& Lee, S. (2015). Impacts of city personality and image on revisit intention. International Journal of Tourism Cities, 1, 50-69.

Kim. H., \& Stepchenkova, S. (2017). Understanding destination personality through visitors' experience: a cross-cultural perspective. Journal of Destination Marketing \& Management, 6, 416-425.

Kim, S., \& Lehto, X. Y. (2013). Projected and perceived destination brand personalities: the case of South Korea. Journal of Travel Research, 52, 117-130.

Kumar, V., \& Nayak, J. K. (2014). The measurement \& conceptualization of destination personality. Tourism Management Perspectives, 12, 88-93. 
Lakoff, G., \& Johnson, M. (2008). Metaphors we live by. $1^{\text {st }}$ (Ed.), Chicago: University of Chicago Press.

Matzler, K., Strobl, A., Stokburger-Sauer, N., Bobovnicky, A., \& Bauer, F. (2016). Brand personality and culture: the role of cultural differences on the impact of brand personality perceptions on tourists' visit intentions. Tourism Management, 52, 507-520.

Mikulic, J., Milicevic, K., \& Kresic, D. (2016). The relationship between brand strength and tourism identity: empirical evidence from the EU capital cities. International Journal of Culture, Tourism and Hospitality Research, 10, 14-23.

Molina, A., Fernandez, A.C., Gomez, M., \& Aranda, E. (2017). Tourism Management, 58, 28-39

Murphy, L., Benckendorff, P., \& Moscardo, G. (2007a). Linking travel motivation, tourist self-image and destination brand personality. Journal of Travel \& Tourism Marketing, 22, 45-59.

Murphy, L., Moscardo, G., \& Benckendorff, P. (2007b). Using brand personality to differentiate regional tourism destinations. Journal of Travel Research, 46, 5-14.

Pan, L., Zhang, M., Gursoy, D., \& Lu, L. (2017). Development and validation of a destination personality scale for mainland Chinese travelers. Tourism Management, 59, $338-348$.

Papadimitriou, D., Apostolopoulou, A., \& Kaplanidou, K. (2013). Destination personality, affective image, and behavioral intentions in domestic urban tourism. Journal of Travel Research, 54, 302-315.

Paxson, J. J. (2009). The Poetics of Personification. Reissue (Ed.), Cambridge, UK: Cambridge University Press. 
Peel, D. \& Lloyd, G. (2008). New communicative challenges: Dundee, place branding and the reconstruction of a city image. Town Planning Review, 79, 507-532.

Pike, S. \& Ryan, C. (2004). Destination positioning analysis through a comparison of cognitive, affective, and conative perceptions. Journal of Travel Research, 42, 333-342.

Pike, S. (2009). Destination brand positioning of a competitive set of near-home destinations. Tourism Management, 30(6), 857-866.

Pitt, L. F., Opoku, R., Hultman, M., Abratt, R., \& Spyropoulou, S. (2007). What I say about myself: communication of brand personality by African countries. Tourism Management, $28,835-844$

Provalis Research. (2010). QDA Miner 4 with WordStat 6. Montreal, Canada.

Rojas-Méndez, J. I., Murphy, S. A., \&Papadopoulos, N. (2013). The US brand personality: a sino perspective. Journal of Business Research, 66, 1028-1034.

Rojas-Méndez, J. I., Papadopoulos, N., \& Alwan, M. (2015). Testing self-congruity theory in the context of nation brand personality. Journal of Product \& Brand Management, 24, 18 27.

Sahin, S., \& Baloglu, S. (2009). Brand personality and destination image of Istanbul: A comparison across nationalities. Paper presented at the 14th annual graduate student research conference in hospitality and tourism, Las Vegas, NV.

Sahin, S., \& Baloglu, S. (2011). Brand personality and destination image of Istanbul. Anatolia-An International Journal of Tourism \& Hospitality Research, 22, 69-88.

Sahin, S., \& Baloglu, S. (2014). City branding: investigating a brand advocacy model for distinct segments. Journal of Hospitality Marketing \& Management, 23, 239-265.

Sirgy, M. J., \& Su, C. (2000). Destination image, self-congruity, and travel behaviour: toward an integrative model. Journal of Travel Research, 38, 340-352. 
Souiden, N., Ladhari, R., \& Chiadmi, N. E. (2017). Destination personality and destination image. Journal of Hospitality \& Tourism Management, 32, 54-70.

Sourial, N., Wolfson, C., Zhu, B., Quail, J., Fletcher, J., Karunananthan, S.,...Bergman, H. (2010). Correspondence analysis is a useful tool to uncover the relationships among categorical variables. Journal of Clinical Epidemiology, 63, 638-646.

Sung, Y., \& Choi, S. M. (2010). The influence of self-construal on self-brand congruity in the United States and Korea. Journal of Cross-Cultural Psychology, 43, 151-166.

Upadhyaya, M. (2012). Influence of destination image and destination personality: An empirical analysis. Journal of Marketing \& Communication, 7(3), 40-47.

Usakli, A., \& Baloglu, S. (2011). Brand personality of tourist destinations: an application of self-congruity theory. Tourism Management, 32, 114-127.

Whitlark, D. B., \& Smith, S. M. (2001). Using correspondence analysis to map relationships. Marketing Research, 13, 22-27.

Xie, K. L., \& Lee, J-S. (2013). Toward the perspective of cognitive destination image and destination personality: the case of Beijing. Journal of Travel \& Tourism Marketing, 30, $538-556$.

Yelland, P. M. (2010). An introduction to correspondence analysis. The Mathematica Journal, 12, 1-23.

Zenker, S. (2009). Who's your target? The creative class as a target group for place branding. Journal of Place Management \& Development, 2(1), 23-32 